\title{
Faktor-Faktor Risiko untuk Terjadinya Retinopati pada Prematuritas
}

\author{
Alfian Nasution
}

\begin{abstract}
Retinopati pada prematuritas pertama diidentifikasi oleh Terry tahun 1942, laporan setelah itu mengatakan selama 10 tahun periode tahun 40 -an sampai 50 -an retinopati pada prematuritas telah menimbulkan kebutaan pada $\mathbf{1 7 . 0 0 0}$ anak di Amerika dan di belahan lain dunia.

Perkembangan ICU neonatus pada akhir dekade 60-an dan kemajuan pesat dalam teknologi penunjang kelangsungan hidup bayi-bayi prematur, bukan hanya meningkatkan jumlah bayi dengan berat badan lahir sangat rendah dapat hidup, tapi juga meningkatkan jumlah bayi yang berisiko terhadap retinopati pada prematuritas bertahan hidup. Hal ini telah membangkitkan kembali minat untuk meneliti dasar-dasar dan perjalanan penyakit ini.

Penelitian terhadap faktor risiko retinopati pada prematuritas mencatat berat badan lahir yang sangat rendah, lamanya pemberian oksigen dan konsentrasi oksigen sebagai factor-faktor yang berperan menentukan munculnya kelainan ini, disamping faktor anemia / transfusi darah, defisiensi vitamin $\mathrm{E}$, paparan cahaya, kadar $\mathrm{CO}_{2}$ tinggi dan sepsis. Beberapa keadaan lain juga dilaporkan sebagai faktor risiko, namun karena belum banyak peneliti lain yang juga menilai faktor yang sama, perannya sebagai faktor risiko atau penolakan peran faktor-faktor tersebut belum begitu jelas, seperti sianosis, apne, ventilasi mekanis, perdarahan intraventrikel, kejang, DAP, preparat xanthine, preparat indometasin, asidosis, hipoksia intrauterin dan distres pernafasan.
\end{abstract}

Kata kunci: prematuritas, retinopati, factor risiko.

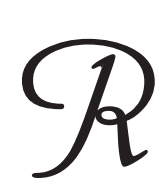

etinopati pada prematuritas (RPP) adalah suatu retinopati proliferatif pada bayi prematur sebagai akibat terpapar pada oksigen konsentrasi tinggi. ${ }^{1}$ Penulis lain memberikan definisi yang bervariasi tetapi pada prinsipnya menunjuk kepada adanya penyakit dengan proliferasi retina akibat terganggunya pembuluh darah retina yang belum terbentuk sempurna. $^{2-7}$

Tulisan ini bertujuan untuk membicarakan masalah retinopati pada prematuritas dengan

Alamat korespondensi:

Dr. Alfian Nasution, Sp.A.

Bagian Ilmu Kesehatan Anak FK-USU / RSUP. H. Adam Malik Medan. Jl. Bunga Lau No. 17, Medan 20136.

Telepon: 061-836 0405, 8360143. Fax. 061-836 1721. penekanan pada pembahasan faktor-faktor risiko untuk terjadinya retinopati pada prematuritas.

Retinopati pada prematuritas pertama diidentifikasi oleh Terry tahun 1942, dari pengamatannya pada epidemi kebutaan diantara bayi-bayi prematur. ${ }^{78}$ Flynn mengutip dari Silvermann, memperkirakan bahwa selama 10 tahun priode 1943 - 1953 RPP telah menimbulkan kebutaan pada 7000 anak di Amerika dan 10.000 anak di seluruh belahan dunia. ${ }^{7}$ Palmer, dkk. ${ }^{9}$ melaporkan $65,8 \%$ bayi dengan $\mathrm{BB} £ 1250$ gram dan $81,6 \%$ bayi dengan $\mathrm{BB} £ 1000$ gram mengalami RPP pada berbagai tingkat dari penelitian pada 4099 bayi BBLR. Phelps ${ }^{10}$ melaporkan angka kebutaan akibat RPP di Amerika Serikat selama tahun 1979 berjumlah 546 kasus dan memperkirakan 2.100 bayi akan terkena RPP 
pada tingkat sikatrik setiap tahun di Amerika Serikat.

Vaskularisasi retina yang normal berawal dari diskus optikus menuju ke perifer dan terbentuk sempurna pada sisi nasal pada usia kehamilan 36 minggu dan pada sisi temporal pada kehamilan 40 minggu. Pemahaman tentang terjadinya RPP ini belum sempurna, namun diduga kuat bahwa jaringan mesenkim bakal pembuluh darah yang tumbuh dari sentral ke perifer retina adalah jaringan yang sensitif terhadap sitotoksisitas sampai terbentuk menjadi pembuluh darah yang matur. Paparan terhadap oksigen yang berlebihan pada periode ini bisa menimbulkan obliterasi dan menghambat vaskularisasi lebih lanjut, sehingga bagian depan retina tidak mendapatkan aliran darah. ${ }^{2,6}$

Diagnosis RPP dibuat atas dasar pemeriksaan optalmoskopi oleh seorang ahli mata yang berpengalaman. Terdapat berbagai protokol pemeriksaan yang dianjurkan untuk mendeteksi kemungkinan adanya RPP. ${ }^{11,12}$ American Academic of Pediatric (AAP) merekomendasikan pemeriksaan untuk mendeteksi kemungkinan adanya pada bayi dengan berat badan < 1300 gram atau usia kehamilan $<35$ minggu yang terpapar oksigen, atau BB $<1000$ gram / usia kehamilan < 30 minggu meskipun tanpa terpapar oksigen. Pemeriksaan dilakukan pada usia bayi $5-7$ minggu sesudah kelahiran. ${ }^{11}$ Komite Internasional untuk klasifikasi RPP (ICROP) pada tahun 1984 membagi RPP berdasarkan lokasi, luas dan beratnya lesi (Tabel 1)..$^{6,11,13}$

Terdapat beberapa macam pilihan terapi dalam penanganan RPP seperti ${ }^{11,14}$

1. Cryopexy circumferential: upaya untuk mencegah progresifitas penyakit dengan cara menghancurkan sel-sel yang melepas faktor angiogenik.

2. Fotokoagulasi laser: data menunjukkan teknik ini sangat efektif dan lebih aman dari cryopexy.

3. Pemberian vitamin E (masih kontroversial).

4. Mengurangi intensitas cahaya: efeknya terhadap insiden RPP masih dipertanyakan.

5. Operasi retina yang lepas (ablasio retina)

6. Vitrektomi tidak memberikan hasil yang lebih baik pada penyakit dengan adanya sikatrik.

Sembilan puluh persen retinopati tingkat I dan II menghilang secara spontan, laporan terbaru juga melaporkan 50\% tingkat III+ hilang secara spontan. Akibat lambat RPP setelah mengalami regresi berupa miopia, strabismus, ambliopia, glaukoma dan ablatio retina yang muncul lambat. ${ }^{11,12}$

\section{Faktor-faktor Risiko Retinopati pada Prematuritas}

Pada waktu pertama kali diidentifikasi oleh Terry tahun 1942 dianggap paparan oksigen dengan konsentrasi tinggi pada bayi prematur adalah satu-satunya faktor yang berperan dalam mekanisme terjadinya RPP. ${ }^{1-5}$

Perkembangan ICU neonatus pada akhir dekade 60-an dan kemajuan pesat dalam tekonologi penunjang kelangsungan hidup bayi-bayi prematur, bukan hanya meningkatkan jumlah bayi dengan berat badan lahir sangat rendah yang bertahan hidup, tapi juga meningkatkan jumlah bayi yang berisiko terhadap RPP. Meningkatnya jumlah BBLR yang bertahan hidup telah membangkitkan kembali minat untuk meneliti dasar-dasar dan perjalanan penyakit ini. Adanya temuan uji krioterapi untuk RPP yang dilakukan secara bersamaan pada beberapa pusat pelayanan bayi dengan berat badan lahir rendah yang memiliki masalah mata /penglihatan (CryoROP Multicentter Trial) telah mengubah cara pandang dokter anak dan dokter mata yang merawat bayi ini terhadap masalah RPP. ${ }^{2}$

Penelitian kolaboratif setelah itu terhadap faktor risiko RPP mencatat berat badan lahir yang sangat

Tabel 1. Pembagian Retinopati pada Prematuritas

Lokasi :Zone

I. Retina posterior dalam area $60 \infty$ lingkaran dengan titik pusat N. optikus.

II. Dari cincin posterior (zone I) ke arah oraserata nasal

III. Sisa daerah retina temporal.

Luas: Luas daerah yang terlibat berdasarkan pembagian zone jam.

Beratnya penyakit :

Tingkat

I. Adanya garis batas antara daerah vaskularisasi dan non-vaskularisasi di retina.

II. Garis batas meninggi / melebar dan berisi (ridge).

III. Ridge diikuti proliferasi fibrovaskular di luar retina.

IV. Lepasnya retina sub-total.

V. Lepasnya retina total disertai funnel.

Penyakit dengan tanda $(+)$ :

Apabila di sekeliling ridge ditemukan pembuluh darah yang melebar dan berkelok-kelok. 
rendah, lamanya pemberian oksigen dan konsentrasi oksigen sebagai faktor yang berperan menentukan munculnya kelainan ini. ${ }^{4}$ Penelitian lain menemukan faktor usia kehamilan, apne yang memerlukan resusitasi dengan sungkup/masker oksigen, sepsis, beratnya penyakit, transfusi darah, perdarahan intraventrikular dan ventilasi mekanik sebagai faktor yang juga perperan meningkatkan risiko kejadian RPP. ${ }^{4,9,15,16}$

\section{Beberapa Faktor Risiko yang Sudah Diidentifikasi}

\section{Penggunaan $\mathrm{O}_{2}$}

Peran oksigen sebagai faktor risiko RPP telah mulai diteliti semenjak era 1950-an diawali oleh penelitian kolaboratif 18 rumah sakit yang dikoordinasi dokter V.E. Kinsey yang kemudian hasil penelitian ini diperkuat oleh penelitian eksperimental lain. ${ }^{4}$

Efek primer oksigen terhadap pembuluh darah retina yang belum matang pada binatang percobaan adalah terjadinya vasokonstriksi retina. Apabila konstriksi ini bertahan akan diikuti oleh penutupan pembuluh darah pada berbagai tingkat, kemudian akan menimbulkan kerusakan endotel dan akan menyebabkan penutupan sempurna pembuluh darah yang belum matang tersebut. Pembuluh darah baru akan terbentuk pada daerah yang mengalami kerusakan kapiler retina tersebut. Pembuluh darah baru ini akan menyebar di permukaan retina dan berkembang sampai ke korpus vitreus. ${ }^{4,15}$

Penelitian dengan binatang percobaan yang diberi oksigen konsentrasi tinggi menunjukkan hanya pembuluh darah yang belum matanglah yang sensitif terhadap oksigen, semakin tidak matang pembuluh darahnya makin besar risikonya terhadap pemberian oksigen, sehingga bayi dengan pembuluh darah retina yang sudah matang / pembuluh darah yang sudah penuh di retina tidak memberi risiko terhadap RPP. Atas dasar itulah predileksi RPP di bagian temporal retina dapat diterangkan. ${ }^{4}$

Vasokonstriksi awal pada pembuluh darah retina yang imatur terjadi dalam beberapa menit pertama setelah paparan terhadap oksigen, ukuran pembuluh darah berkurang sampai $50 \%$, namun kemudian kembali ke ukuran normal. Oksigen yang dilakukan terus menerus $4-6$ jam selama akan menimbulkan vasospasme bertahap sampai pembuluh darah tersebut mengecil sampai $80 \%$. Sampai pada tahap ini vasokonstriksi pembuluh darah retina masih bersifat reversibel, namun apabila keadaan ini bertahan (misalnya pemberian oksigen sampai $10-15$ jam) beberapa pembuluh darah perifer retina yang belum matur tersebut akan mengalami penutupan permanen. ${ }^{4}$

\section{Anemia dan Transfusi Darah}

Beberapa peneliti melaporkan transfusi darah atau anemia sebagai faktor risiko RPP, namun laporan ini masih diperdebatkan. Beberapa penelitian menyimpulkan bahwa anemia adalah faktor risiko untuk terjadinya RPP sedangkan laporan lain mengatakan hematokrit yang tinggi dan transfusi berulang pada kejadian anemia yang merupakan faktor independen terjadinya kasus RPP. ${ }^{8}$ Sacks, dkk. ${ }^{18}$ pada penelitian 90 bayi dengan $\mathrm{BB} £ 1250$ gram (Pennsylvania, 1980) menemukan hubungan yang bermakna antara kejadian RPP dengan transfusi tukar. Clark, dkk. ${ }^{19}$ menemukan hubungan yang bermakna antara insiden RPP dengan transfusi darah pada penelitian 58 bayi dengan $\mathrm{BB} £ 1000$ gram dan 70 bayi dengan berat lahir rendah yang mendapatkan terapi oksigen dengan berbagai variasi berat badan.

Anemia pada BBLR yang kemudian ditangani dengan pemberian transfusi darah berulang akan menyebabkan bayi menerima sejumlah darah dari orang dewasa (donor dewasa). Masuknya darah dari orang dewasa ini meningkatkan risiko RPP yang dihubungkan dengan peningkatan penumpukan zat besi pada bayi-bayi prematur ini. Hal ini akan meningkatkan aktivitas anti oksidan yang terkait dengan penumpukan zat besi. ${ }^{7,20}$ Brooks $d k k$, pada penelitian 50 bayi dengan $\mathrm{BB} \leq 1250$ gram tidak menemukan perbedaan insiden RPP antara kelompok bayi yang diberikan transfusi untuk mengatasi anemia (24 bayi) dengan kelompok bayi yang diberikan transfusi untuk mempertahankan kadar hematokrit $>40 \%$ (26 bayi). ${ }^{8}$

\section{Defisiensi Vitamin E}

Flynn mengutip dari Owens dan Owens melaporkan peran vitamin E dalam mencegah kejadian RPP pada kelompok bayi prematur. Pemberian $50 \mathrm{mg}$ vitamin E secara oral tiga kali sehari bersamaan dengan dimulainya pemberian makanan peroral diketahui dapat menekan insiden RPP. Penelitian ini dilakukan 
pada bayi-bayi dengan $\mathrm{BB} \leq 1360$ gram. ${ }^{7,15}$ Payne mengutip dari Kretzer dan Hittner, memperlihatkan adanya perubahan dasar pada struktur sel spindel retina bayi-bayi prematur berisiko tinggi. Sel spindel retina bayi prematur yang mendapat oksigen secara terus menerus akibat distres pernafasan memperlihatkan peningkatan gapjunction, diyakini bahwa peningkatan Gap Junction ini mengganggu proses pembentukan pembuluh darah yang normal. Pada bayi prematur yang mendapat vitamin E peningkatan gap junction dapat ditekan. ${ }^{15}$

Vitamin E secara invitro merupakan anti oksidan lipofilik yang poten, sedangkan kadar vitamin ini pada bayi prematur lebih rendah sehingga keterkaitan ini menjadi dasar asumsi faktor risiko RPP. Namun sulit untuk dibuktikan bahwa peningkatan kadar vitamin E di dalam serum bayi akan dapat mencegah kejadian RPP. ${ }^{20}$ Pemberian vitamin E pada bayi prematur diketahui memiliki beberapa kemungkinan efek samping seperti enterokolitis nekrotikans, sepsis, perdarahan intra ventrikular, perdarahan retina, perubahan respons imun dan penekanan aktifitas

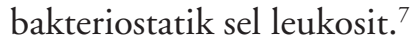

\section{Paparan Cahaya}

Cahaya terang yang mengenai mata bayi prematur diduga menimbulkan pengaruh untuk terjadinya RPP, namun masih terdapat perbedaan pendapat terhadap mekanisme terjadinya ROP dalam hubungan dengan paparan cahaya terang pada tempat perawatan bayi intensif.,16 Glass, ${ }^{21}$ melaporkan bahwa bayi prematur yang dirawat di ruangan dengan cahaya terang benderang 32\% lebih besar peluangnya terkena RPP dibanding mata bayi yang mendapat perlindungan dari paparan cahaya, meskipun hasil ini tidak secara kuat menunjuk kepada pengaruh cahaya pada retinopati pada prematurias, tapi Glass menyatakan bahwa tidak ada satupun penelitian yang menyatakan cahaya fluoresen aman bagi mata bayi. Reynold, dkk. ${ }^{22}$ pada penelitian 188 bayi prematur yang mendapatkan paparan cahaya terkontrol dengan cara memberikan pencahayaan ruangan memakai lampu yang berputar (hidup-mati), dengan kontrolnya bayi yang terpapar cahaya terang terus menerus, mendapatkan hasil bahwa pengurangan intensitas cahaya ini (399 Lux untuk kelompok studi dan 447 Lux untuk kelompok kontrol) tidak mengubah insiden RPP (53\% kelompok studi dan $52 \%$ kelompok kontrol). Hasil yang didapat pada penelitian ini sangat dipengaruhi oleh perbedaan intensitas paparan yang tidak terlalu besar.

\section{Karbondioksida}

Retensi $\mathrm{CO}_{2}$ dapat meningkatkan efek kerusakan pembuluh darah retina bayi prematur oleh terapi suplementasi oksigen. ${ }^{7,16}$ Patz mengutip dari Baner dan Widmayer ${ }^{4}$ melaporkan bahwa retensi $\mathrm{CO}_{2}$ adalah faktor tunggal terpenting yang membedakan insiden RPP pada penelitiannya pada bayi dengan berat badan lahir < 1000 gram, namun Biglan dan Brown tidak melihat pengaruh retensi $\mathrm{CO}_{2}$ terhadap insiden RPP dan malah menemukan bayi dengan RPP tingkat lanjut memiliki $\mathrm{PCO}_{2}$ serum yang lebih rendah dari kelompok kontrol.

\section{Septikemia}

Beberapa penulis melaporkan septikemia sebagai salah satu faktor risiko untuk terjadinya RPP. ${ }^{4}$ Gunn, dkk. ${ }^{23}$ pada penelitian 150 bayi prematur dengan berat badan $\leq 1500$ gr dan mendapatkan suplementasi oksigen, melaporkan sepsis sebagai faktor yang sangat kuat hubungannya dengan kejadian RPP. Mittal, dkk,. ${ }^{24}$ melaporkan bahwa sepsis oleh kandida adalah faktor risiko yang berdiri sendiri dalam memperberat kejadian RPP dan menyebabkan bayi prematur tersebut membutuhkan terapi bedah laser.

\section{Faktor Risiko Lain}

Beberapa keadaan juga dilaporkan sebagai faktor risiko untuk timbulnya RPP, namun karena belum banyak peneliti lain yang juga menilai faktor yang sama, perannya sebagai faktor risiko atau penolakan peran faktor-faktor tersebut belum begitu jelas. Termasuk disini seperti sianosis, apne, ventilasi mekanis, perdarahan intraventrikular, kejang, PDA, preparat xanthine, preparat indometasin, asidosis, hipoksia intrauterin, distres pernafasan. ${ }^{4,7,16}$

Dari semua faktor risiko yang sudah diteliti tampak adanya perbedaan pendapat di antara para peneliti tentang peran masing-masing faktor risiko tersebut untuk terjadinya RPP, sehingga masih diperlukan banyak penelitian untuk menjelaskan potensi risiko masing-masing faktor tersebut secara terpisah (independent). ${ }^{16}$

Kita cenderung berpikiran bahwa RPP adalah 
penyakit yang disebabkan oleh terpaparnya bayi prematur terhadap berbagai faktor risiko setelah lahir, pada kenyataannya ada bayi yang sudah mengalami threshold ROP pada hari pertama atau kedua kehidupan yang memberi kesan bahwa retinopati sudah terjadi intrauterin sebelum bayi terpapar dengan berbagai faktor risiko setelah lahir. Ogden memperkirakan sepertiga kasus RPP lebih dipengaruhi oleh faktor-faktor prenatal dibanding faktor-faktor setelah lahir. ${ }^{16}$

\section{Ringkasan}

- Peningkatan jumlah bayi prematur yang bertahan hidup akibat kemajuan perawatan di NICU telah meningkatkan jumlah bayi yang berpeluang terkena RPP.

- Beberapa keadaan telah diidentifikasi sebagai faktor risiko terjadinya RPP seperti paparan pada oksigen konsentrasi tinggi, anemia-transfusi, defisiensi vitamin E, paparan pada cahaya terang, kadar $\mathrm{O}_{2}$ serum yang tinggi serta septikemia, di samping beberapa faktor lain yang belum begitu jelas perannya.

- Masih diperlukan banyak penelitian untuk menjelaskan besarnya potensi risiko masingmasing faktor tersebut secara terpisah.

\section{Daftar Pustaka}

1. Kansky JJ. Retinal vascular disorders. Dalam: Kansky JJ, penyunting. Clinical opthalmology. Edisi ke-3. London: Butterworth Heinemann, 1994. h. 374-6.

2. Quinn GE. Retinopathy of prematurity. Dalam: Spitzeral, penyunting. Intensive care of the fetus and neonate. St Luois: Mosby, 1996. h. 657-68.

3. Miller SJH. Diseases of retina. Dalam: Miller SJH, penyunting. Person's disease of the eye. Edisi ke-18. Edinburg: Churchill Livingstone, 1990. h. 231-9.

4. Patz A, Palmer EA. Retinopathy of prematurity. Dalam: Schachat AP, Murphy RB, Patz A, penyunting. Retina Volume II. St Louis: Mosby, 1989. h. 509-30.

5. Langston DP. Retina and vitreous. Dalam: Langston DP, penyunting. Manual of ocular diagnosis and therapy. Edisi ke-4. Boston: Little Brown, 1995. h. 155-80.

6. American Academic of Opthalmology. Retina and vitreous. Basic and Clinical Science course section USA, 1997. h. 92-100.

7. Flynn JT. Retinopathy of prematurity. Dalam: Nelson
LB, Calhoun JH, Harley RD, penyunting. Pediatric opthalmology. Edisi ke-3. Philadelphia: Sounders, 1991. h. 59-77.

8. Brooks SE, dkk. The effect of blood transfussion protocol on retinopathy of prematurity a prospective, Randomized study. Pediatrics, 1999; 104:514-18.

9. Palmer EA, Flynn JT, Hardy RJ, dkk. Incident and early course of retinopathy of prematurity. Opthalmology 1991; 98:1628-40.

10. Phelps DL. Retinopathy of prematurity: An estimate of vision loss in the United States - 1979. Pediatric, 1981; 98:1628-40.

11. Grasber JE. Retinopathy of prematurity. Dalam: Gonella TL, penyunting. Menonatology: Management, procedures, on call problems, diseases, and drugs. Edisi ke-4. Stamford: Appleton \& Lange 1999. h. 520-3.

12. Flynn JT, Bancalari E, Bachynski BN, Buckley EB, dkk. Retinopathy of prematurity diagnosis, saverity and natural history. Opthalmology 1987; 94:620-9.

13. The committee for the classfification of retinopathy of prematurity. Dalam: An international classification of retinopathy of prematurity. Arch Opthalmology 1984; 102:1130-4.

14. Cryotherapy for retinopathy of prematurity cooperative group. Multicenter trial of cryotherapy for retinopathy of prematurity. Arch Opthalmology 1988; 106:471-9.

15. Payne JW. Retinopathy of prematurity. Dalam: Avery ME, Taeusch HW, penyunting. Disease of the newborn. Edisi ke-5. Philadelphia: Sounders, 1984. h. 909-13.

16. Risk factor for retinopathy of prematurity. Country Hills eye center. Dikutip dari: http://www.connections.com/ eyedoc/roprisk.html.

17. Patz A, Haeck LE, Dela couz E. Studies on the effect of high oxygen administration in retrocental fibroplasea. Arch Opthalmology 1983; 4:1248-52.

18. Sacks LM, Schaffer DB, Anday EK, Peckam GJ, Papadopoulos MD. Retrolental fibroplasea and blood transfussion in very low birth weight infants. Pediatric 1981; 68: 770-4.

19. Clark C, Gibbs JAH, Maniello R, Outerbridge EW, Aranda JV. Blood transfussion: A posxible risk factor in retrolental fibroplasia. Acta Pediatr Scond 1981; 70:5359.

20. Sullivan L. Iron, plasma antioxidants and the oxygen radical of prematurity. AJDC 1988; 142:1341-4.

21. What causes retinopathy of prematurity. Dikutip dari: com/pbpb-c.html" http://www.rdcbraille. com/pbpbc.html.

22. Reynolds JD, Hardy RJ, Kennedy KA, Spencer R, Van Heuven WAJ, Fielder AR. Effect of light reduction on retinopathy of prematurity (Linght-ROP). N Engl J Med 1998; 338:1572-6.

23. Gunn TR, Easdown J, Outerbridge EW, Aranda JV. Risk factors in retrolental fibroplasia. Pediatrics 1980; 65:1096-100.

24. Mittal M, Dhanireddy R, Higgins RD. Candida sepsis and association with retinopathy of prematurity. Pediatrics 1998; 101:654-7. 